USGS Science to Support the USGS Changing Arctic Ecosystems Initiative

\title{
Historical and Contemporary Imagery to Assess Ecosystem Change on the Arctic Coastal Plain of Northern Alaska
}
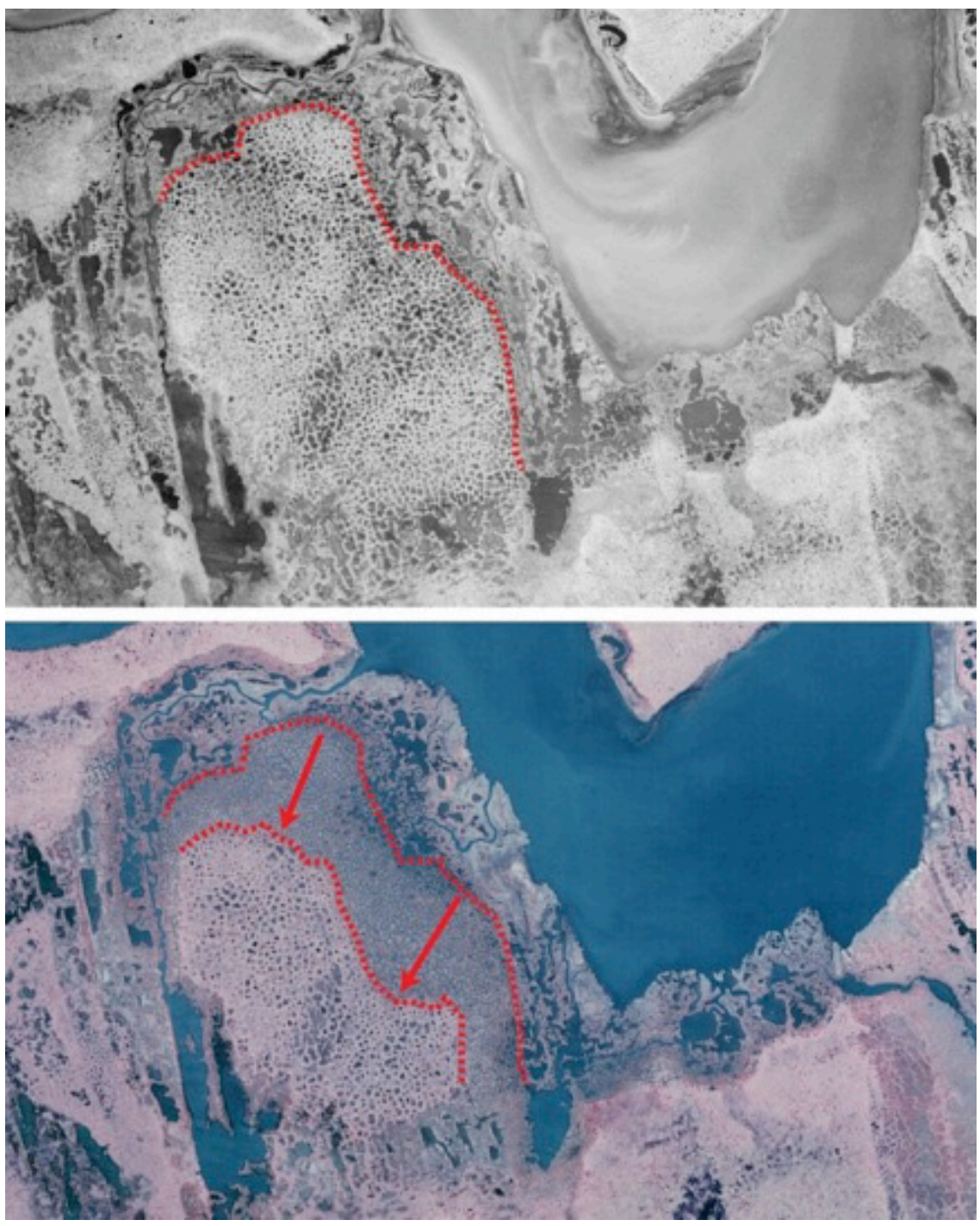

Open-File Report 2014-1140

Version 1.1, June 2015 



\section{Historical and Contemporary Imagery to Assess Ecosystem Change on the Arctic Coastal Plain of Northern Alaska}

By Ken D. Tape, John M. Pearce, Dennis Walworth, Brandt W. Meixell, Tom F. Fondell, David D. Gustine, Paul L. Flint, Jerry W. Hupp, Joel A. Schmutz, and David H. Ward

USGS Science to Support the USGS Changing Arctic Ecosystems Initiative

Open-File Report 2014-1140

Version 1.1, June 2015

U.S. Department of the Interior

U.S. Geological Survey 


\title{
U.S. Department of the Interior SALLY JEWELL, Secretary
}

\section{U.S. Geological Survey \\ Suzette M. Kimball, Acting Director}

\author{
U.S. Geological Survey, Reston, Virginia \\ First release: 2014 \\ Revised June 2015 (ver. 1.1)
}

\begin{abstract}
For more information on the USGS-the Federal source for science about the Earth, its natural and living resources, natural hazards, and the environment-visit http://www.usgs.gov or call 1-888-ASK-USGS
\end{abstract}

For an overview of USGS information products, including maps, imagery, and publications, visit http://www.usgs.gov/pubprod

To order this and other USGS information products, visit http://store.usgs.gov

\begin{abstract}
Suggested citation:
Tape, K.D., Pearce, J.M., Walworth, Dennis, Meixell, B.W., Fondell, T.F., Gustine, D.D., Flint, P.L., Hupp, J.W., Schmutz, J.A., and Ward, D.H., 2014, Historical and contemporary imagery to assess ecosystem change on the Arctic coastal plain of northern Alaska (ver. 1.1, June 2015): U.S. Geological Survey Open-File Report 2014-1140, 22 p., http://dx.doi.org/10.3133/ofr20141140.
\end{abstract}

ISSN 2331-1258 (online)

Any use of trade, product, or firm names is for descriptive purposes only and does not imply endorsement by the U.S. Government.

Although this report is in the public domain, permission must be secured from the individual copyright owners to reproduce any copyrighted material contained within this report. 


\section{Contents}

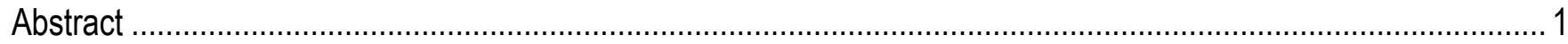

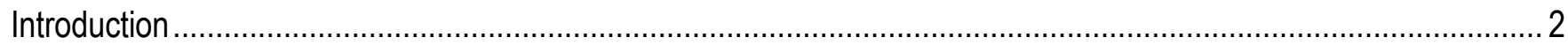

Study Areas, Scientific Objectives, and Associated Imagery ..................................................................... 4

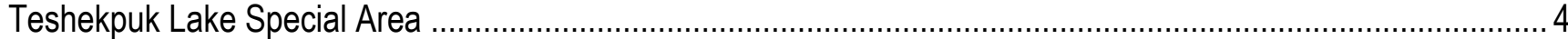

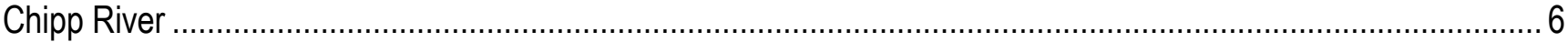

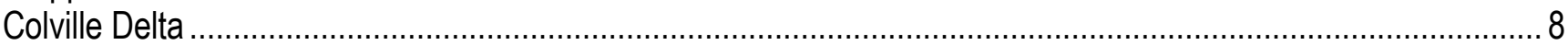

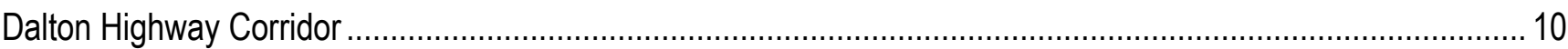

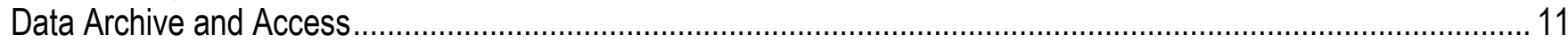

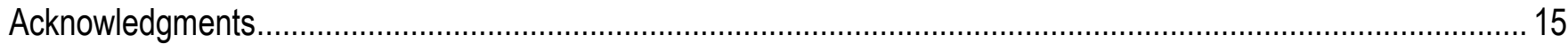

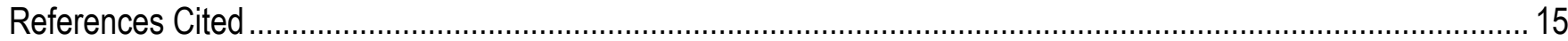

Appendix 1. Mosaic Showing Select Historical and Contemporary Imagery to Assess Ecosystem Change on the TLSA Coast Study Area on the Arctic Coastal Plain of Northern Alaska ...................................... 18

Appendix 2. Mosaic Showing Select Historical and Contemporary Imagery to Assess Ecosystem Change on the Chipp River Study Area on the Arctic Coastal Plain of Northern Alaska.......................................20

Appendix 3. Mosaic Showing Select Historical and Contemporary Imagery to Assess Ecosystem Change on the Colville River Delta Study Area on the Arctic Coastal Plain of Northern Alaska...... Appendix 4. Mosaic Showing Select Historical and Contemporary Imagery to Assess Ecosystem Change on the Dalton Highway Corridor Study Area on the Arctic Coastal Plain of Northern Alaska

\section{Figures}

Figure 1. Northern Alaska showing the Arctic Coastal Plain, Brooks Range, and the location of the four main study areas described in the text where historical and contemporary imagery were obtained

Figure 2. Images from 1948 and 2002, showing an area of subsiding ice wedge polygonal ground near the mouth of Garry Creek within the TLSA Coast study area

Figure 3. Images from July 11, 1948 and July 19, 2002, showing areas in the Chipp River study area of lake drainage during the period between photographs.

Figure 4. Images from 1948 to 1949 and 2009 showing new water flow paths (blue arrows) on the Colville Delta study area where lakes have breached ice wedge polygonal ground.

Figure 5. Images from 1949 and 2009 to 2010

\section{Table}

Table 1. List of aerial images described in this report 
This page left intentionally blank 


\title{
Historical and Contemporary Imagery to Assess Ecosystem Change on the Arctic Coastal Plain of Northern Alaska
}

By Ken D. Tape ${ }^{1}$, John M. Pearce², Dennis Walworth², Brandt W. Meixell2, Tom F. Fondell ${ }^{2}$, David D. Gustine $^{2}$, Paul L. Flint², Jerry W. Hupp², Joel A. Schmutz², and David H. Ward²

\begin{abstract}
The Arctic Coastal Plain of northern Alaska is a complex landscape of lakes, streams, and wetlands scattered across low-relief tundra that is underlain by permafrost. This region of the Arctic has experienced a warming trend over the past three decades leading to thawing of onshore permafrost and the disappearance of sea ice at unprecedented rates. The U.S. Geological Survey's (USGS) Changing Arctic Ecosystems (CAE) research initiative was developed to investigate and forecast these rapid changes in the physical environment of the Arctic, and the associated changes to wildlife populations, in order to inform key management decisions by the U.S. Department of the Interior and other agencies. Forecasting future wildlife responses to changes in the Arctic can benefit greatly from historical records that inform what changes have already occurred. Several Arctic wildlife and plant species have already responded to climatic and physical changes to the Arctic Coastal Plain of northern Alaska. Thus, we located historical aerial imagery to improve our understanding of recent habitat changes and the associated response to such changes by wildlife populations.

In this report, we describe and make available a set of 61 georectified aerial images of the Arctic Coastal Plain (taken from 1948 to 2010) that were obtained by the USGS to inform research objectives of the USGS CAE Initiative. Here, we describe the origins, metadata, and public availability of these images that were obtained within four main study areas on the Arctic Coastal Plain: Teshekpuk Lake Special Area, Chipp River, the Colville River Delta, and locations along the Dalton Highway Corridor between the Brooks Range and Deadhorse. We also provide general descriptions of observable changes to the geomorphology of landscapes that are apparent by comparing historical and contemporary images. These landscape changes include altered river corridors, lake drying, coastal erosion, and new vegetation communities. All original and georectified images and metadata are publically available for download.
\end{abstract}

\footnotetext{
${ }^{1}$ Institute of Northern Engineering, University of Alaska Fairbanks, 306 Tanana Loop, Fairbanks, Alaska, 99775.

${ }^{2}$ U.S. Geological Survey, Alaska Science Center, 4210 University Dr., Anchorage, Alaska, 99508.
} 


\section{Introduction}

Climate-related physical changes, such as warming temperatures, diminishing sea ice, increasing coastal erosion, and deteriorating permafrost, are taking place in the Arctic and are affecting wildlife populations through (1) alterations in animal behavior (Jay and others, 2012; Herriman and Peacock, 2014), (2) changes in abundance and distribution (Flint and others, 2014), and (3) changes to soil and vegetation (Martin and others, 2009; Tape and others, 2013). Increasing temperatures and shifts in hydrologic regimes have facilitated the conversion of tussock tundra to shrubs (Tape and others, 2006), increased the biomass of vegetation in the Arctic biome (Martin and others, 2009), and advanced the onset and extended the duration of the growing season (Goetz and others, 2005). Herbivores in northern latitudes, such as caribou (Rangifer tarandus) and species of migratory geese, rely on the high plant quantity and quality in the Arctic for reproduction, feather molt, migration, and winter survival (Barboza and Hume, 2006; Flint and others, 2008). Consequently, the predominant effects of climate warming to populations of northern herbivores are likely to be nutritionally mediated through changes in vegetative phenology and productivity during the summer (Klein and others, 2005). Assessing long-term changes in vegetation types and distribution will help to better understand the potential impacts of future 'bottom-up' effects to populations of northern herbivores.

Changes in size and distribution of several populations of migratory geese in the Arctic may be linked to alterations to vegetation and phenology (earlier spring snow melt and plant emergence). For example, increasing breeding populations of lesser snow geese (Chen caerulescens) and greater white-fronted geese (Anser albifrons), and a continuing distributional shift in molting Pacific black brant (Branta bernicla nigricans) toward the Arctic coast over the past 30 years (Flint and others, 2008; Lewis and others, 2010, 2011), appear to be associated with the conversion of coastal tundra to salt-inundated sedge meadows (Serreze and others, 2007; Arp and others, 2010; Tape and others, 2013; Flint and others, 2014). However, we have a poor understanding of the full spatial and temporal extent of vegetative and phenological changes and the associated implications of these changes to populations of herbivores, such as caribou and geese on the Arctic Coastal Plain of northern Alaska.

In 2010, the U.S. Geological Survey (USGS) initiated the Changing Arctic Ecosystems (CAE) research initiative (Geiselman and others, 2012), which is intended to inform management decisions by helping managers understand how wildlife populations will respond to the rapid physical changes in the Arctic (Oakley and others, 2012; Pearce and others, 2012; McNew and others, 2013). A main objective of the USGS CAE initiative is to understand the physical changes in Arctic environments that are occurring as a result of climate warming during the 20th and 21 st centuries and to determine how these changes may impact wildlife populations now and in the future. 
In this report, we describe and make available a series of georectified aerial imagery from various sources that were used to detect landscape changes in areas of interest to wildlife scientists and managers. Our main objective was to make available a series of overlapping historical (1940s), intermediate (1970s), and contemporary (2000s) imagery that can be used to assess vegetative and landscape changes important to Arctic wildlife, such as herbivores (caribou and geese, that feed primarily on grass and other plants,), but potentially also piscivores (animals, such as loons that feed primarily on fish), and invertivores (animals, such as shorebirds that feed primarily on invertebrates). We describe the origins, metadata, and public availability of these images, which were obtained within four main study areas on the Arctic Coastal Plain (fig. 1). We also summarize some of the general landscape changes detected by comparing historical and contemporary photographs, and put these in context of USGS CAE research questions.

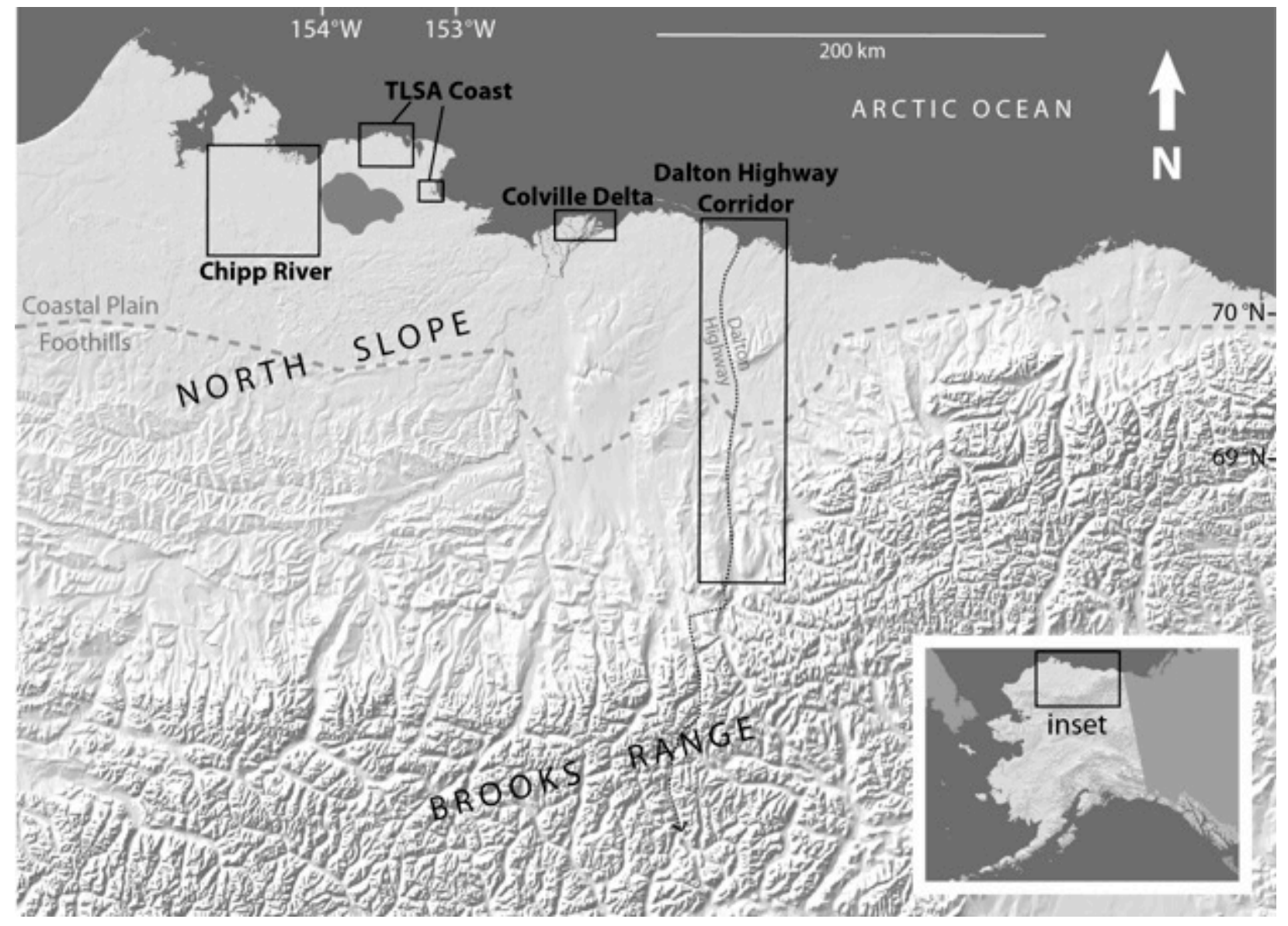

Figure 1. Northern Alaska showing the Arctic Coastal Plain, Brooks Range, and the location of the four main study areas described in the text where historical and contemporary imagery were obtained. 


\section{Study Areas, Scientific Objectives, and Associated Imagery}

Historical and contemporary imagery was obtained for four main study areas on the Arctic Coastal Plain of northern Alaska, where a portion of USGS CAE research is focused. These areas were:

- Smith River and Garry Creek drainages in the coastal zone of the Teshekpuk Lake Special Area (TLSA Coast),

- An interior lake area west of Teshekpuk Lake (Chipp River),

- Coastal areas of the Colville River Delta (Colville Delta), and

- Ten locations along the Dalton Highway between the Brooks Range and Deadhorse (Dalton Highway Corridor) (fig. 1).

For each study area, we obtained historical imagery from the Alaska Satellite Facility (ASF) at the University of Alaska Fairbanks (https://www.asf.alaska.edu/). Images were black and white $9 \times 9$ in. photographic prints from 1948 and 1949. ASF images were scanned at 1,200 dots-per-inch grayscale and georectified to various contemporary (2002-10) satellite imagery (table 1) using tie-point methods and splines for interpolation (Tape and others, 2013). Imagery from intervening periods (1955 USGS mapping efforts and 1977-82 Alaska High Altitude Photography) was acquired from USGS Earth Explorer http://earthexplorer.usgs.gov/) and University of Alaska's Geographic Information Network of Alaska (GINA;

http://www.gina.alaska.edu/) and georectified. All original and georectified imagery (table 1) and associated metadata are archived at the USGS Alaska Science Center. The total time series of aerial imagery was acquired to examine evidence for landscape change in Arctic Alaska between the earliest set of imagery (1948-49) and the most recent (2002-10). Imagery from intervening periods was acquired to constrain the timing of any observed landscape change between the historical and contemporary images.

\section{Teshekpuk Lake Special Area}

The main objective for the TLSA Coast imagery was to determine the timing and extent of vegetation and landscape changes of coastal wetlands occupied by molting geese. The TLSA (figs. 1 and 2, appendix 1) annually supports 80,000-90,000 geese during their annual flightless wing molting period (Flint and others, 2008), making it the most significant goose molting area in the Arctic (Derksen and others, 1979). Recent research has identified significant increases in the number of molting greater white-fronted geese and in the shifts in the spatial distribution of molting Pacific black brant over the past 30 years in the TLSA Coast. Molting black brant have shifted from primarily inland, freshwater lakes towards coastal, brackish wetlands (Flint and others, 2008). Of these coastal wetlands, the Smith River and Garry Creek wetland complexes (within the TLSA Coast study areas, figs. 1 and 2) best exemplify the significant changes in distribution and habitat use of molting black brant. Virtually unused in the 1970-1980s, the Smith River and Garry Creek wetlands now support upwards of 20,000 black brant geese during the flightless period (Tape and others, 2013). Furthermore, during late July and early August, when most black brant have regained flight, coastal wetlands, such as the Smith River and Garry Creek, support more black brant than all other freshwater wetlands in the TLSA Coast combined 
(Lewis and others, 2010). Landscape-scale changes concurrent with the habitat shifts of molting brant across the Arctic Coastal Plain are a result of climate warming. Thawing of permafrost and shrinking of summer pack ice extent have increased rates of coastal erosion, which in turn has increased the frequency and extent of saltwater intrusion into coastal tundra areas. Consequently, the plant communities of coastal areas recently inundated by storm surges have likely undergone a succession towards salt-tolerant species. These newly colonized salt-tolerant plant species are known to be favored food items of black brant in other coastal areas of Alaska, explaining the redistribution of black brant (Tape and others, 2013).
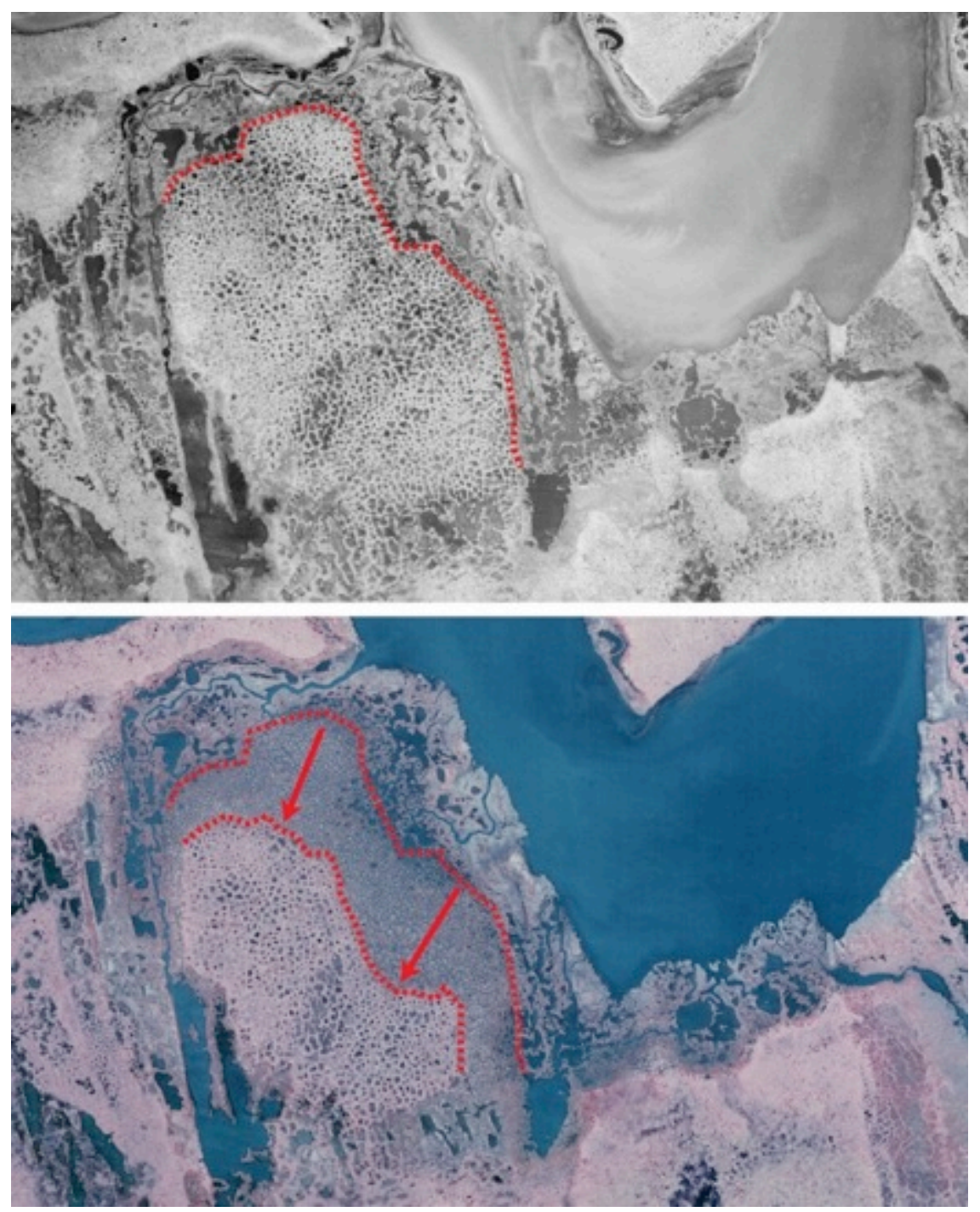

Figure 2. Images from 1948 (top, table 1: image 23) and 2002 (bottom, table 1: image 28), showing an area of subsiding ice wedge polygonal ground near the mouth of Garry Creek within the TLSA Coast study area. Images are 2.8 kilometers wide. The red dotted lines indicate the location of the subsidence front in 1948 (top line) and 2008 (bottom line), and the arrows indicate the movement during that interval. 
For the TLSA Coast study area, we acquired and georectified 15 images from the 1948 to 1949 ASF set, 1 image from the 1955 USGS cartographic effort, and 5 images from the 1977 to 1982 USGS Earth Explorer (EE) set (figs. 1 and 2, table 1). Imagery was acquired and scanned from the Smith River and Garry Creek, where recent changes in the spatial distribution of geese have been observed. Time series imagery revealed a redistribution of ice-wedge polygonal ground along the coast that we hypothesize is occurring in response to greater marine water influence as sea-ice extent decreases (Tape and others, 2013). Imagery comparisons also showed changes to the geometry of the mouth of the Smith River since 1948, and that erosion of the coastline is ongoing. The ponds and the river channel of the Smith River estuary have been in the same locations since 1948, yet they are consistently larger in the intermediate (1979) and contemporary (2002 and 2009-10) imagery (Tape and others, 2013). In the Garry Creek estuary, the redistribution of polygonal ground is more evident (fig. 2) and has resulted in conversion to salt tolerant sedge habitat that is important to foraging geese.

\section{Chipp River}

Within the Chipp River study area (figs. 1 and 3, appendix 2) the main objective was to compare historical and contemporary imagery to inform rates and processes of lake drying that may influence food sources, such as plants, fish, and invertebrates to avian consumers including geese, loons, and shorebirds. This information will inform the temporal and spatial dynamics of wetland connections on the Arctic Coastal Plain. Physical connections among lakes and to streams are vital for fish passage (Haynes and others, 2013), but these connections are variable in size and ephemeral due to the high seasonal and annual variance in water volumes moving through these systems in this relatively flat landscape. Because loons are piscivores, their food requirements may be strongly influenced by these water regimes. The yellow-billed loon (Gavia adamsii) is a species of conservation concern in Alaska, and most of the U.S. breeding population occurs on the Arctic Coastal Plain (Earnst and others, 2005). Recent research on the Arctic Coastal Plain suggests that changes in lake water levels related to climate change may affect loon nesting habitat preferences more quickly than other factors, such as fish community composition (Haynes and others, 2014). Implications of lake drying for shorebirds include increases in lake water temperature affecting emergence and abundance of invertebrate forage. For geese, changes in wetland water levels, soil moisture, and subtle differences in elevation may influence development of plant communities favored by these geese for forage.

For the Chipp River study area, we georectified six images from the 1948 to 1949 ASF set and six images from the 1977 to $1982 \mathrm{EE}$ set, using recent imagery from multiple sets as base imagery (table 1). Imagery from the 2002 to 2010 GINA set will be used to identify drained lakes, and then sequentially older imagery will inform possible dates of drying or partial drying. Imagery comparisons revealed that some lakes in the Chipp River study area have dried or partially dried during various time frames between 1949 and 2002 (fig. 3). 

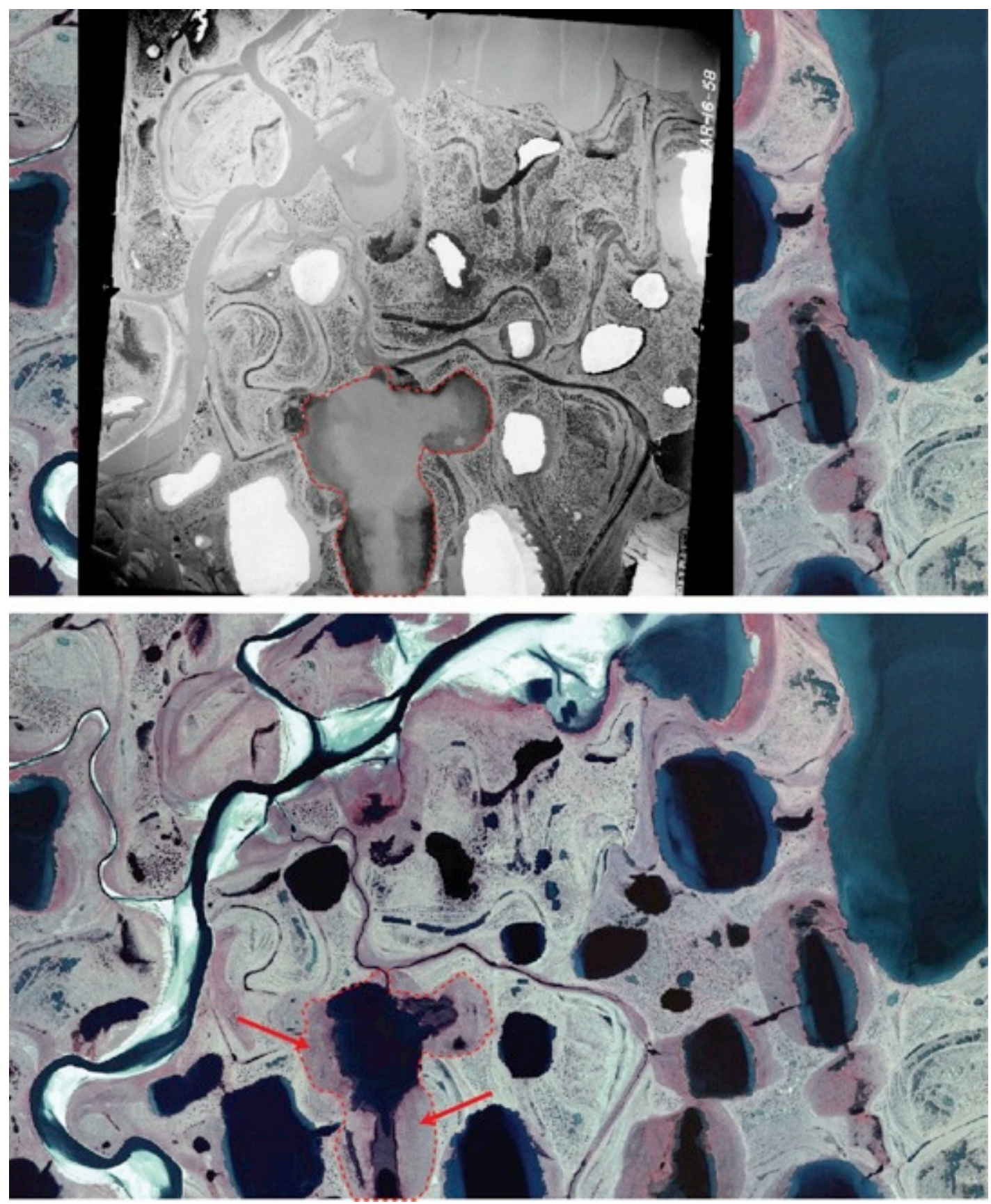

Figure 3. Images from July 11, 1948 (top, table 1: image 34) and July 19, 2002 (bottom, table 1: image 33), showing areas in the Chipp River study area of lake drainage during the period between photographs. Dotted red lines indicate the lakeshore in 1949 and arrows indicate areas where new emergent vegetation has been observed. Images are 7.4 kilometers wide. 


\section{Colville Delta}

Within the Colville Delta study area (figs. 1 and 4, appendix 3), we are using historical aerial imagery to identify areas most vulnerable to predicted vegetation changes. We are quantifying long-term changes in plant phenology across different biomes of Alaska and assessing the ability for Arctic migrants to alter their timing of migration and reproduction in response to these changes. There is evidence that global climate change has altered the phenology of spring vegetative growth (green-up) and has extended the growing season of plants at high northern latitudes (Myeni and others, 1997). However, it is unclear how these changes vary across habitats and whether avian migrants have adapted to shifts in plant phenology by modifying the timing of migration and nesting. Lack of synchrony between plant phenology and these key life-cycle events is often called the 'phenological mismatch' hypothesis, which can have significant consequences for population dynamics and distribution of bird species (Visser and Both, 2005; Visser and others, 2011).

For the Colville Delta study area, we georectified eight images from the 1948 to 1949 ASF set using 2009 imagery (table 1). Comparison of images from 1948 and 2010 (fig. 4) showed new hydrological pathways within the Colville Delta study area where lakes and river channels have breached ice wedge polygonal ground. 

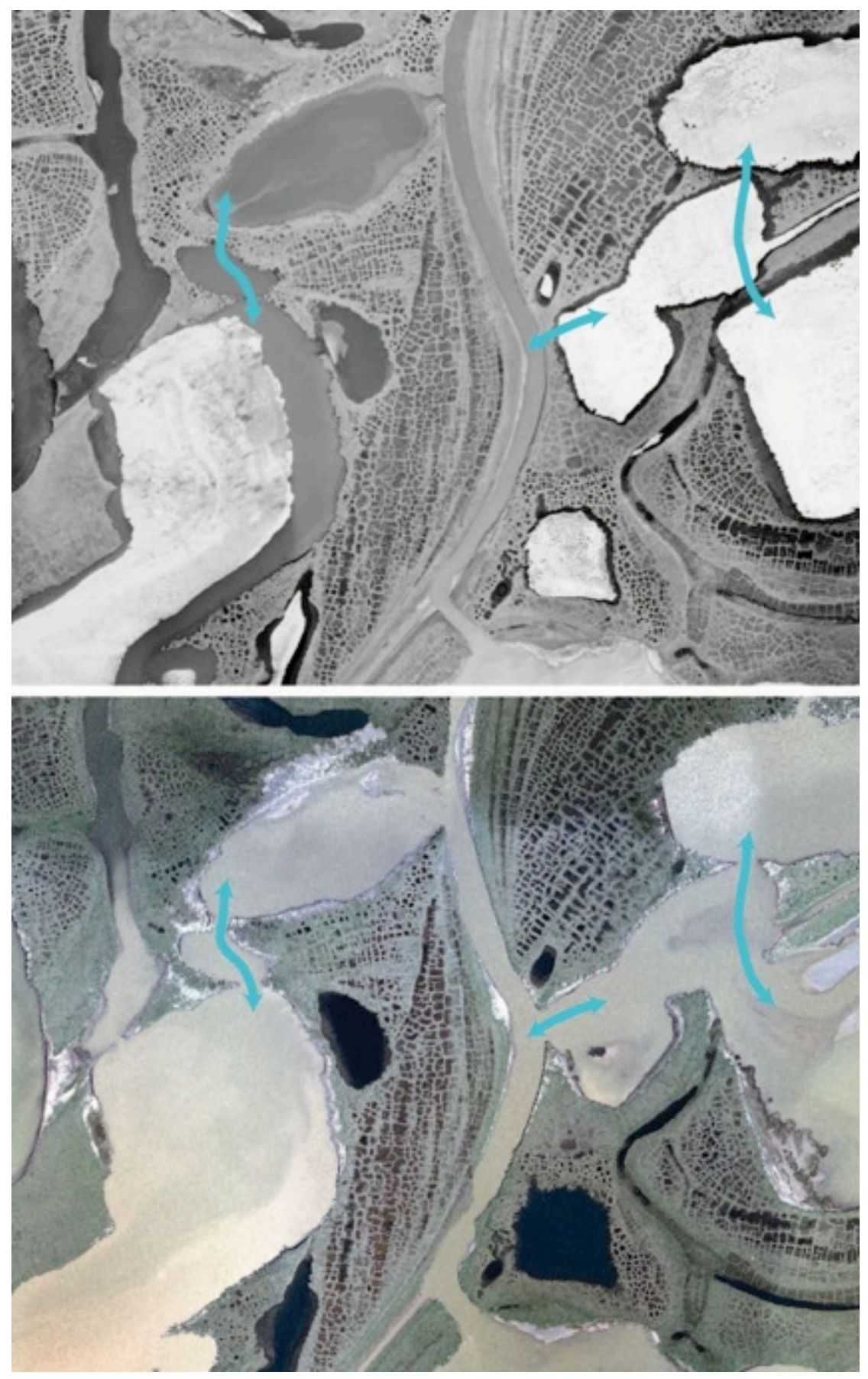

Figure 4. Images from 1948 to 1949 (top, table 1: image 48) and 2009 (bottom, table 1: image 54) showing new water flow paths (blue arrows) on the Colville Delta study area where lakes have breached ice wedge polygonal ground. Images are 2.9 kilometers wide. 


\section{Dalton Highway Corridor}

As part of the USGS CAE initiative, we are evaluating changes in phenology and community structure of forage plants over a 30-year timeframe along the elevational gradient of coastal plain habitats that is transected by the Dalton Highway Corridor south of Deadhorse, Alaska (figs. 1 and 5, appendix 4). Climate change will influence the distribution and quality of habitats utilized by Arctic Coastal Plain ungulates, such as caribou and moose (Alces alces). We expect habitat-based effects on ungulate populations to be largely driven by adjustments in the annual phenological regime and changes in distribution and composition of major habitat types. Furthermore, migratory caribou will likely face important climate-driven changes on their winter ranges (Gustine and others, 2014). In the late 1970s, Whitten and Cameron (1980) documented the phenology and quality of caribou and muskox (Ovibus moschatus) forages at seven sites along the Dalton Highway Corridor. Thirty years later, we are repeating vegetation surveys at these seven sites using long-term sampling plots to assess changes in seasonal plant phenology and forage quality. We are also comparing historical and contemporary satellite imagery to quantify broad changes in vegetation and landscapes in this area. This work will quantify the effects of documented warming over the last 30 years on patterns of forage growth and quality and will provide the basis for reasonable projections regarding effects of future climate change on ungulate forage.

ASF imagery from 1948 to 1949 for seven locations where long-term plots are located along the Dalton Highway Corridor (figs. 1 and 5) was scanned and georectified using a 2009-10 image mosaic (table 1, image 19). 


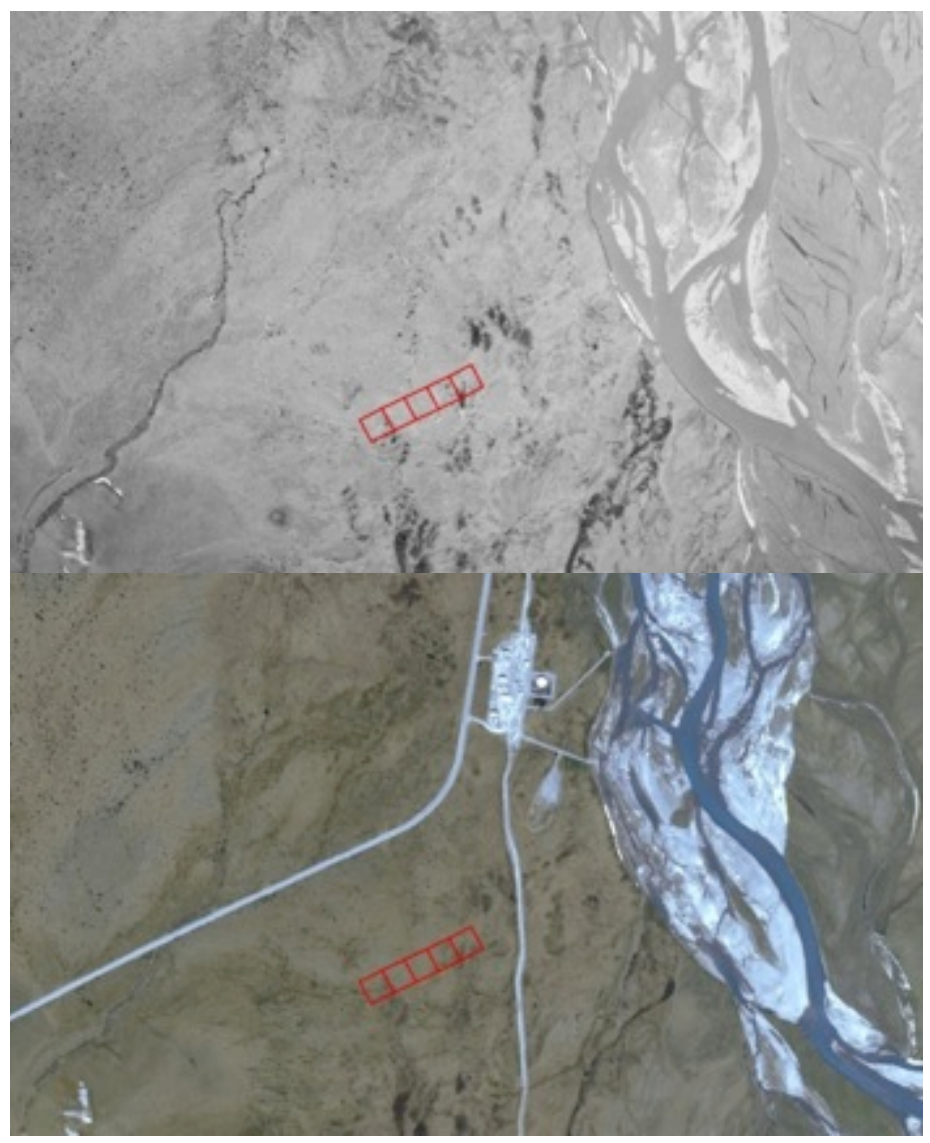

Figure 5. Images from 1949 (top, table 1: image 59) and 2009 to 2010 (bottom, table 1: image 19). Red squares show location of U.S. Geological Survey long-term vegetation plots. Images are 3.8 kilometers wide.

\section{Data Archive and Access}

All images, data, and associated metadata are archived at the USGS Alaska Science Center. Images that were not modified from their original source can be accessed at the host websites for the University of Alaska's Geographic Information Network of Alaska (GINA; http://www.gina.alaska.edu/) (table 1). Images that were georectified from their original source (table 1) and their associated metadata are publically available for download, grouped by date range (1948-1949: http://dx.doi.org/10.5066/F79021TB; 1955:

http://dx.doi.org/10.5066/F757192K; 1974-1979: http://dx.doi.org/10.5066/F71G0J9D ). Metadata files were created using Metavist 2005 (Rugg, 2004). Geographic coordinates of image centerpoints are shown in the appendices. 
Table 1. List of aerial images described in this report.

[See figure 1 and appendixes 1-4. Image No.: Numbers correspond to bounding boxes in appendix maps for each study area. Image source: ASF, University of Alaska Fairbanks GeoData Center, operated by the Alaska Satellite Facility (http://www.asf.alaska.edu/); U.S. Geological Survey Earth Explorer (EE) (http://earthexplorer.usgs.gov/); GINA, University of Alaska Geographic Information Network of Alaska (http://www.gina.alaska.edu/); USGS, U.S. Geological Survey]

\begin{tabular}{|c|c|c|c|c|}
\hline $\begin{array}{l}\text { Image } \\
\text { No. }\end{array}$ & Filename & Date of image & $\begin{array}{l}\text { Image } \\
\text { source }\end{array}$ & $\begin{array}{l}\text { Geo-rectified } \\
\text { or original }\end{array}$ \\
\hline \multicolumn{5}{|c|}{ TLSA Coast (Smith River) } \\
\hline 1 & $\begin{array}{l}\text { TLSA_Coast_georectified_landcover_Teshekpuk_1 } \\
\text { 948-08-08_61-8.tif }\end{array}$ & $8 / 8 / 1948$ & ASF & Georectified \\
\hline 2 & $\begin{array}{l}\text { TLSA_Coast_georectified landcover_- } \\
\text { Teshekpuk } 1948-08-08 \quad 61-100 \quad 8.8 .48 . \text { tif }\end{array}$ & $8 / 8 / 1948$ & ASF & Georectified \\
\hline 3 & $\begin{array}{l}\text { TLSA_Coast_georectified landcover_- } \\
\text { Teshekpuk_1948-08-08_61-98.tif }\end{array}$ & $8 / 8 / 1948$ & ASF & Georectified \\
\hline 4 & $\begin{array}{l}\text { TLSA_Coast_georectified landcover_- } \\
\text { Teshekpuk 1948-08-08 61-96.tif }\end{array}$ & $8 / 8 / 1948$ & ASF & Georectified \\
\hline 5 & $\begin{array}{l}\text { TLSA_Coast_georectified_landcover_ } \\
\text { Teshekpuk_1948-08-08_61-94.tif }\end{array}$ & $8 / 8 / 1948$ & ASF & Georectified \\
\hline 6 & $\begin{array}{l}\text { TLSA_Coast_georectified landcover } \\
\text { Teshekpuk } 1948-08-08 \text { - } 61-36 \quad 8.8 .48 \text {.tif }\end{array}$ & $8 / 8 / 1948$ & ASF & Georectified \\
\hline 7 & $\begin{array}{l}\text { TLSA_Coast_georectified landcover } \\
\text { Teshekpuk_1948-08-08 } 61-34 \quad 8.8 . \overline{4} \text {.tif }\end{array}$ & $8 / 8 / 1948$ & ASF & Georectified \\
\hline 8 & $\begin{array}{l}\text { TLSA_Coast_georectified landcover } \\
\text { Teshekpuk_1948-08-08 } 61-32 \quad 8.8 . \overline{4} \text {.tif }\end{array}$ & $8 / 8 / 1948$ & ASF & Georectified \\
\hline 9 & $\begin{array}{l}\text { TLSA_Coast_georectified landcover } \\
\text { Teshekpuk_1948-08-08_61-30_8.8.48.tif }\end{array}$ & $8 / 8 / 1948$ & ASF & Georectified \\
\hline 10 & $\begin{array}{l}\text { TLSA_Coast_georectified landcover_- } \\
\text { Teshekpuk_1955-06-21_6.21.55.tif }\end{array}$ & $6 / 21 / 1955$ & ASF & Georectified \\
\hline 11 & $\begin{array}{l}\text { TLSA_Coast_georectified_landcover_ } \\
\text { Teshekpuk_1974-06-21_6.21.74.tif }\end{array}$ & $6 / 21 / 1974$ & ASF & Georectified \\
\hline 12 & $\begin{array}{l}\text { TLSA_Coast_georectified landcover } \\
\text { Teshekpuk_1948-08-08_EE_7.15.79_3116.tif }\end{array}$ & $7 / 15 / 1979$ & $\mathrm{EE}$ & Georectified \\
\hline 13 & tesd1ne.tif & $7 / 19 / 2002$ & GINA & Original \\
\hline 14 & tesd1sw.tif & $7 / 19 / 2002$ & GINA & Original \\
\hline 15 & tesd1nw.tif & $7 / 19 / 2002$ & GINA & Original \\
\hline 16 & hard5nw.tif & $7 / 19 / 2002$ & GINA & Original \\
\hline 17 & hard5sw.tif & $7 / 19 / 2002$ & GINA & Original \\
\hline 18 & tesd1se.tif & $7 / 19 / 2002$ & GINA & Original \\
\hline 19 & tape_large_aoi_image_clip_aa.tif & 2009-2010 & GINA & Original \\
\hline \multicolumn{5}{|c|}{ TLSA Coast (Garry Creek) } \\
\hline 20 & $\begin{array}{l}\text { TLSA_Coast_georectified_landcover_ } \\
\text { HarrisonBay } 1948-07-17 \text { 81-158.tif }\end{array}$ & $7 / 17 / 1948$ & ASF & Georectified \\
\hline 21 & $\begin{array}{l}\text { TLSA_Coast_georectified_landcover_ } \\
\text { HarrisonBay_1948-07-17_81-160.tif }\end{array}$ & $7 / 17 / 1948$ & ASF & Georectified \\
\hline 22 & $\begin{array}{l}\text { TLSA_Coast_georectified_landcover_ } \\
\text { HarrisonBay } 1948-08-08 \text { 81-129.tif }\end{array}$ & $7 / 17 / 1948$ & ASF & Georectified \\
\hline 23 & $\begin{array}{l}\text { TLSA_Coast_georectified_landcover_ } \\
\text { HarrisonBay_1948-08-08_81-127.tif }\end{array}$ & $7 / 17 / 1948$ & ASF & Georectified \\
\hline
\end{tabular}




\begin{tabular}{|c|c|c|c|c|}
\hline $\begin{array}{l}\text { Image } \\
\text { No. }\end{array}$ & Filename & Date of image & $\begin{array}{l}\text { Image } \\
\text { source }\end{array}$ & $\begin{array}{l}\text { Geo-rectified } \\
\text { or original }\end{array}$ \\
\hline \multicolumn{5}{|c|}{ TLSA Coast (Garry Creek)-Continued } \\
\hline 24 & $\begin{array}{l}\text { TLSA_Coast_georectified } \\
\text { landcover_HarrisonBay_1977-07-31_EE_0017.tif }\end{array}$ & $7 / 31 / 1977$ & $\mathrm{EE}$ & Georectified \\
\hline 25 & $\begin{array}{l}\text { TLSA_Coast_georectified } \\
\text { landcover HarrisonBay 1977-15-79 EE 3218.tif }\end{array}$ & $7 / 15 / 1979$ & $\mathrm{EE}$ & Georectified \\
\hline 26 & $\begin{array}{l}\text { TLSA_Coast_georectified } \\
\text { landcover_HarrisonBay_1977-07-31_EE_0010.tif }\end{array}$ & $7 / 31 / 1977$ & $\mathrm{EE}$ & Georectified \\
\hline 27 & harc5ne.tif & $7 / 19 / 2002$ & GINA & Original \\
\hline 28 & harc5se.tif & $7 / 19 / 2002$ & GINA & Original \\
\hline 29 & harc5sw.tif & $7 / 19 / 2002$ & GINA & Original \\
\hline 30 & harc5nw.tif & $7 / 19 / 2002$ & GINA & Original \\
\hline \multicolumn{5}{|c|}{ TLSA Coast (Piasuk River) } \\
\hline 31 & $\begin{array}{l}\text { TLSA_Coast_georectified } \\
\text { landcover_Teshekpuk_1948-9_23-121.tif }\end{array}$ & $1948-49$ & ASF & Georectified \\
\hline 32 & $\begin{array}{l}\text { TLSA_Coast_georectified } \\
\text { landcover_Teshekpuk_1948-9 23-119.tif }\end{array}$ & $1948-49$ & ASF & Georectified \\
\hline 33 & cir_photos_2002_mosaic.img & $7 / 19 / 2002$ & USGS & Original \\
\hline \multicolumn{5}{|c|}{ Chipp River } \\
\hline 34 & $\begin{array}{l}\text { Chipp_River_georectified } \\
\text { landcover_Teshekpuk_1948-07-11_16-59.tif }\end{array}$ & $7 / 11 / 1948$ & ASF & Georectified \\
\hline 35 & $\begin{array}{l}\text { Chipp_River_georectified } \\
\text { _landcover_Teshekpuk_1948-07-11_16-57.tif }\end{array}$ & $7 / 11 / 1948$ & ASF & Georectified \\
\hline 36 & $\begin{array}{l}\text { Chipp_River_georectified } \\
\text { landcover_Teshekpuk_1948-07-11_16-91.tif }\end{array}$ & $7 / 11 / 1948$ & ASF & Georectified \\
\hline 37 & $\begin{array}{l}\text { Chipp_River_georectified } \\
\text { landcover Teshekpuk } 1948 \quad 1949 \quad 23-119 . t i f\end{array}$ & $1948-49$ & ASF & Georectified \\
\hline 38 & $\begin{array}{l}\text { Chipp_River_georectified } \\
\text { _landcover_Teshekpuk_1948_1949_4-135.tif }\end{array}$ & $1948-49$ & ASF & Georectified \\
\hline 39 & $\begin{array}{l}\text { Chipp_River_georectified } \\
\text { landcover_Teshekpuk_1948_1949_4-158.tif }\end{array}$ & $1948-49$ & ASF & Georectified \\
\hline 40 & $\begin{array}{l}\text { Chipp_River_georectified } \\
\text { landcover_Teshekpuk_1979-07-15_EE_3200.tif }\end{array}$ & $7 / 15 / 1979$ & $\mathrm{EE}$ & Georectified \\
\hline 41 & $\begin{array}{l}\text { Chipp_River_georectified } \\
\text { landcover_Teshekpuk_1979-07-15_EE_3202.tif }\end{array}$ & $7 / 15 / 1979$ & $\mathrm{EE}$ & Georectified \\
\hline 42 & $\begin{array}{l}\text { Chipp_River_georectified } \\
\text { landcover_Teshekpuk_1979-07-15_EE_3140.tif }\end{array}$ & $7 / 15 / 1979$ & EE & Georectified \\
\hline 43 & $\begin{array}{l}\text { Chipp_River_georectified } \\
\text { landcover_Teshekpuk_1977-07-31_EE_0030.tif }\end{array}$ & $7 / 31 / 1977$ & $\mathrm{EE}$ & Georectified \\
\hline 44 & $\begin{array}{l}\text { Chipp_River_georectified } \\
\text { landcover_Teshekpuk 1979-07-15 EE 3273.tif }\end{array}$ & $7 / 15 / 1979$ & $\mathrm{EE}$ & Georectified \\
\hline 45 & $\begin{array}{l}\text { Chipp_River_georectified } \\
\text { landcover_Teshekpuk_1979-07-15_EE_3279.tif }\end{array}$ & $7 / 15 / 1979$ & EE & Georectified \\
\hline
\end{tabular}




\begin{tabular}{|c|c|c|c|c|}
\hline $\begin{array}{l}\text { Image } \\
\text { No. }\end{array}$ & Filename & Date of image & $\begin{array}{l}\text { Image } \\
\text { source }\end{array}$ & $\begin{array}{c}\text { Geo-rectified } \\
\text { or original }\end{array}$ \\
\hline \multicolumn{5}{|c|}{ Colville Delta } \\
\hline 46 & $\begin{array}{l}\text { Colville_Delta_georectified } \\
\text { landcover HarrisonBay } 1948 \quad 1949 \text { 77-186.tif }\end{array}$ & $1948-49$ & ASF & Georectified \\
\hline 47 & $\begin{array}{l}\text { Colville_Delta_georectified } \\
\text { _landcover_HarrisonBay_1948_1949_77-188.tif }\end{array}$ & $1948-49$ & ASF & Georectified \\
\hline 48 & $\begin{array}{l}\text { Colville_Delta_georectified } \\
\text { landcover_HarrisonBay_1948_1949_272-120.tif }\end{array}$ & $1948-49$ & ASF & Georectified \\
\hline 49 & $\begin{array}{l}\text { Colville_Delta_georectified } \\
\text { landcover HarrisonBay } 1948 \quad 1949 \quad 272-122 . t i f\end{array}$ & $1948-49$ & ASF & Georectified \\
\hline 50 & $\begin{array}{l}\text { Colville_Delta_georectified } \\
\text { landcover_HarrisonBay_1948_1949_272-124.tif }\end{array}$ & $1948-49$ & ASF & Georectified \\
\hline 51 & $\begin{array}{l}\text { Colville_Delta_georectified } \\
\text { landcover HarrisonBay } 1948 \quad 1949 \quad \text { 272-126.tif }\end{array}$ & $1948-49$ & ASF & Georectified \\
\hline 52 & $\begin{array}{l}\text { Colville_Delta_georectified } \\
\text { landcover_HarrisonBay_1948_1949_272-128.tif }\end{array}$ & $1948-49$ & ASF & Georectified \\
\hline 53 & $\begin{array}{l}\text { Colville_Delta_georectified } \\
\text { landcover HarrisonBay } 1948 \quad 1949 \quad 272-130 . \text { tif }\end{array}$ & $1948-49$ & ASF & Georectified \\
\hline 54 & $\overline{\mathrm{C}} \mathrm{RDv0112}$ larger.bsq & 2009 & USGS & Original \\
\hline \multicolumn{5}{|c|}{ Dalton Highway Corridor } \\
\hline 55 & $\begin{array}{l}\text { Dalton_Highway_Corridor_georectified } \\
\text { landcover 1948 } 1949 \text { BeecheyPoint 278-6.tif }\end{array}$ & $1948-49$ & ASF & Georectified \\
\hline 56 & $\begin{array}{l}\text { Dalton_Highway_Corridor_georectified } \\
\text { landcover } 1948 \text { - } 1949 \text { BeecheyPoint 280-123.tif }\end{array}$ & $1948-49$ & ASF & Georectified \\
\hline 57 & $\begin{array}{l}\text { Dalton_Highway_Corridor_georectified } \\
\text { landcover_1949-07-15_275-1.tif }\end{array}$ & $7 / 15 / 1949$ & ASF & Georectified \\
\hline 58 & $\begin{array}{l}\text { Dalton_Highway_Corridor_georectified } \\
\text { landcover_1949-06-23_207-12.tif }\end{array}$ & $6 / 23 / 1949$ & ASF & Georectified \\
\hline 59 & 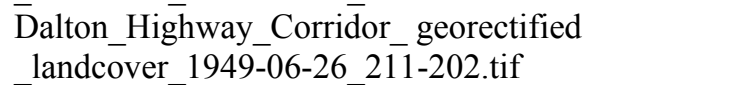 & $6 / 26 / 1949$ & ASF & Georectified \\
\hline 60 & 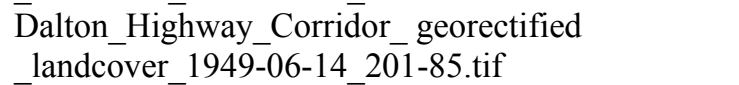 & $6 / 14 / 1949$ & ASF & Georectified \\
\hline 61 & 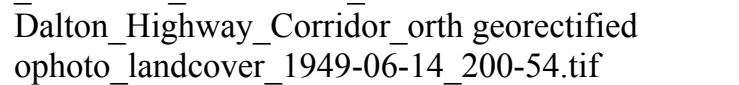 & $6 / 14 / 1949$ & ASF & Georectified \\
\hline
\end{tabular}




\section{Acknowledgments}

We thank S. Smith and B. Anderson (USGS), J. Grunblatt (GINA), V. Wolf (University of Alaska, Fairbanks), and K. Homan (Southeast Alaska GIS Library) for assistance with metadata processing, archiving of data, and data access. The University of Alaska, Fairbanks, GeoData Center operated by the Alaska Satellite Facility graciously allowed us access to the 1948-49 photographic prints. This work is part of the U.S. Geological Survey's Changing Arctic Ecosystem Initiative and is supported by funding from the Wildlife Program of the USGS Ecosystem Mission Area. T. DeGange, L. Tibbitts, and B. Uher-Koch provided helpful reviews on an earlier version of this paper.

\section{References Cited}

Arp, C.D., Jones, B.M., Schmutz, J.A., Urban, F.E., and Jorgenson, M.T., 2010, Two mechanisms of aquatic and terrestrial habitat change along an Alaska Arctic coastline: Polar Biology, v. 33, p. 1629-1640, doi:10.1007/s00300-1010-0800-5.

Barboza, P.S., and Hume, I.D., 2006, Physiology of intermittent feeding-Integrating responses of vertebrates to nutritional deficit and excess: Physiological and Biochemical Zoology, v. 79, p. 250-264, doi:10.1086/499984.

Derksen, D.V., Weller, M.W., and Eldridge, W.D., 1979, Distributional ecology of geese molting near Teshekpuk Lake, National Petroleum Reserve-Alaska, in Jarvis, R.L., and Bartonek, J.C., eds., Management and biology of pacific Flyway geese: Corvallis, Oregon State University, p. 189-207.

Earnst, S.L., Stehn, R.A., Platte, R.M., Larned, W.W., and Mallek, E.J., 2005, Population size and trend of yellow-billed loons in northern Alaska: Condor, v. 107, p. 289-304, doi: $10.1650 / 7717$.

Flint, P., Mallek, E., King, R., Schmutz, J., Bollinger, K., and Derksen, D., 2008, Changes in abundance and spatial distribution of geese molting near Teshekpuk Lake, AlaskaInterspecific competition or ecological change?: Polar Biology, v. 31, no. 5, p. 549-556, doi:10.1007/s00300-007-0386-8.

Flint, P.L., Meixell, B.W., and Mallek, E.J., 2014, High fidelity does not preclude colonizationRange expansion of molting Black Brant on the Arctic coast of Alaska: Journal of Field Ornithology, v. 85, p. 75-83, doi:10.1111/jofo.12051.

Geiselman, J.A., DeGange, A.R., Oakley, K.L., Derksen, D.V., and Whalen, M.E., 2012, Changing Arctic Ecosystems - Research to understand and project changes in marine and terrestrial ecosystems of the Arctic: U.S. Geological Survey Fact Sheet 2011-3136, 4 p. [Also available at http://pubs.er.usgs.gov/publication/fs20113136.]

Goetz, S.J., Bunn, A.G., Fiske, G.J., and Houghton, R.A., 2005, Satellite-observed photosynthetic trends across boreal North America associated with climate and fire disturbance: Proceedings of the National Academy of Sciences, v. 102, p. 13,521-13,525, doi:10.1073/pnas.0506179102.

Gustine, D.D., Brinkman, T.J., Lindgren, M.A., Schmidt, J.I., Rupp, T.S., and Adams, L.G., 2014, Climate-driven effects of fire on winter habitat for caribou in the Alaskan-Yukon Arctic: PLoS One, v. 9, p. e100588, doi: 10.1371/journal.pone.0100588. 
Haynes, T.B., Rosenberger, A.E., Lindberg, M.S., Whitman, M., and Schmutz, J.A., 2013, Method- and species-specific detection probabilities of fish occupancy in Arctic lakesImplications for design and management: Canadian Journal of Fisheries and Aquatic Sciences, v. 70, p. 1,055-1,062, doi: 10.1139/cjfas-2012-0527.

Haynes, T.B., Schmutz, J.A., Lindberg, M.S., and Rosenberger, A.E., 2014, Risk of predations and weather events affect nest site selection by sympatric Pacific (Gavia pacifica) and Yellowbilled (Gavia adamsii) loons in Arctic habitats, in Paruk, J.D., Mager, J.N., III, Evers, D.C., and Jones, S.L., eds., Waterbirds_-Loon research and conservation in North America: Waterbird Society, v. 37, Special Publication 1 \#, p.16-25.

Herriman, J., and Peacock, E., 2014, Polar bear use of a persistent food subsidy-Insights from non-invasive genetic sampling in Alaska: Ursus, v. 24, p. 148-163, doi: 10.2192/URSUS-D12-00030.1.

Jay, C.V., Fischbach, A.S., and Kochnev, A.A., 2012, Walrus areas of use in the Chukchi Sea during sparse sea ice cover: Marine Ecology Progress Series, v. 468, p. 1-13, doi: $10.3354 /$ meps 10057.

Klein, D.R., Baskin, L.M., Bogoslovskaya, L.S., Danell, K., Gunn, A., Irons, D.B., Kofinas, G.P., Kovacs, K.M., Magomedova, M., Meehan, R.H., Russell, D.E., and Valkenburg, P., 2005, Management and conservation of wildlife in a changing arctic environment, in Symon, C., Arris, L., and Heal, B., eds., Arctic climate impact assessment: Cambridge University Press, New York, p. 597-648.

Lewis, T.L., Flint, P.L., Derksen, D.V., and Schmutz, J.A., 2011, Fine scale movements and habitat use of black brant during the flightless wing molt in Arctic Alaska: Waterbirds, v. 34, p. 177-185, doi:10.1675/063.034.0206.

Lewis, T.L., Flint, P.L., Schmutz, J.A., and Derksen, D.V., 2010, Temporal and spatial shifts in habitat use by black brant immediately following flightless molt: The Wilson Journal of Ornithology, v. 122, p. 484-493, doi :10.1676/09-114.1.

Martin, P.D., Jenkins, J.L., Adams, F.J., Jorgenson, M.T., Matz, A.C., Payer, D.C., Reynolds, P.E., Tidwell, A.C., and Zelenak, J.R., 2009, Wildlife response to environmental arctic change-Predicting future habitats of Arctic Alaska.: U.S. Fish and Wildlife Service, 138 p., http://www.fws.gov/alaska/wildreach.htm (accessed 19 May 2014).

McNew, L., Handel, C., Pearce, J., DeGange, T., Holland-Bartels, L., and Whalen, M., 2013, Changing Arctic ecosystems - The role of ecosystem changes across the Boreal-Arctic transition zone on the distribution and abundance of wildlife populations: U.S. Geological Survey Fact Sheet 2013-3054, 2 p. [Also available at http://pubs.usgs.gov/fs/2013/3054/.]

Myeni, R.B., Keeling, C.D., Tucker, C.J., Asrar, G., and Nemani, R.R., 1997, Increased plant growth in the northern high latitudes from 1981 to 1991: Nature, v. 386, p. 698-702, doi: doi:10.1038/386698a0.

Oakley, K., Whalen, M., Douglas, D., Udevitz, M., Atwood, T., and Jay, C., 2012, Polar bear and walrus response to the rapid decline in Arctic sea ice: U.S. Geological Survey Fact Sheet 2012-3131, 4 p. [Also available at http://pubs.usgs.gov/fs/2012/3131/.]

Pearce, J., DeGange, T., Flint, P., Fondell, T., Gustine, D., Holland-Bartels, L., Hope, A., Hupp, J., Koch, J., Schmutz, J., Talbot, S., Ward, D., and Whalen, M., 2012, Changing Arctic Ecosystems-Measuring and forecasting the response of Alaska's terrestrial ecosystem to a warming climate., 4 p. [Also available at http://pubs.usgs.gov/fs/2012/3144/.] 
Rugg, D.J., 2004, Creating FGDC and NBII metadata with Metavist 2005: Saint Paul, Minn., U.S. Department of Agriculture, Forest Service, North Central Research Station, 30 p., accessed May 19, 2014, at http://ncrs.fs.fed.us/pubs/gtr/gtr nc255.pdf.

Serreze, M.C., Holland, M.M., and Stroeve, J., 2007, Perspectives on the Arctic's Shrinking SeaIce Cover: Science, v. 315, p. 1,533-1,536, doi: 10.1126/science.1139426.

Tape, K.D., Flint, P.L., Meixell, B.W., and Gaglioti, B.V., 2013, Inundation, sedimentation, and subsidence creates goose habitat along the Arctic coast of Alaska: Environmental Research Letters, v. 8, p. 045031, doi:10.1088/1748-9326/8/4/045031.

Tape, K., Sturm, M., and Racine, C., 2006, The evidence for shrub expansion in Northern Alaska and the Pan-Arctic: Global Change Biology, v. 12, p. 686-702, doi:10.1111/j.13652486.2006.01128.x.

Visser, M.E., and Both, C., 2005, Shifts in phenology due to global climate change-The need for a yardstick: Proceeding of Royal Society for Biological Sciences, v. 272, p. 2,561-2,569, doi:10.1098/rspb.2005.3356.

Visser, M.E., Marvelde, L., and Marjolein, M.E., 2011, Adaptive phenological mismatches of birds and their food in a warming world: Journal of Ornithology, v. 153, p. 75-84, doi:10.1007/s10336-011-0770-6.

Whitten, K.R., and Cameron, R.D., 1980, Nutrient dynamics of caribou forage on Alaska's Arctic Slope, in Reimers, E., Gaare, E., and Skjenneberg, S., eds., Proceedings of the Second International Reindeer/Caribou Symposium, Røros, Norway, 1897: Trondheim, Norway, Direktoratet for vilt og ferskvannsfisk, p. 159-166. 
Appendix 1. Mosaic Showing Select Historical and Contemporary Imagery to Assess Ecosystem Change on the TLSA Coast Study Area on the Arctic Coastal Plain of Northern Alaska.

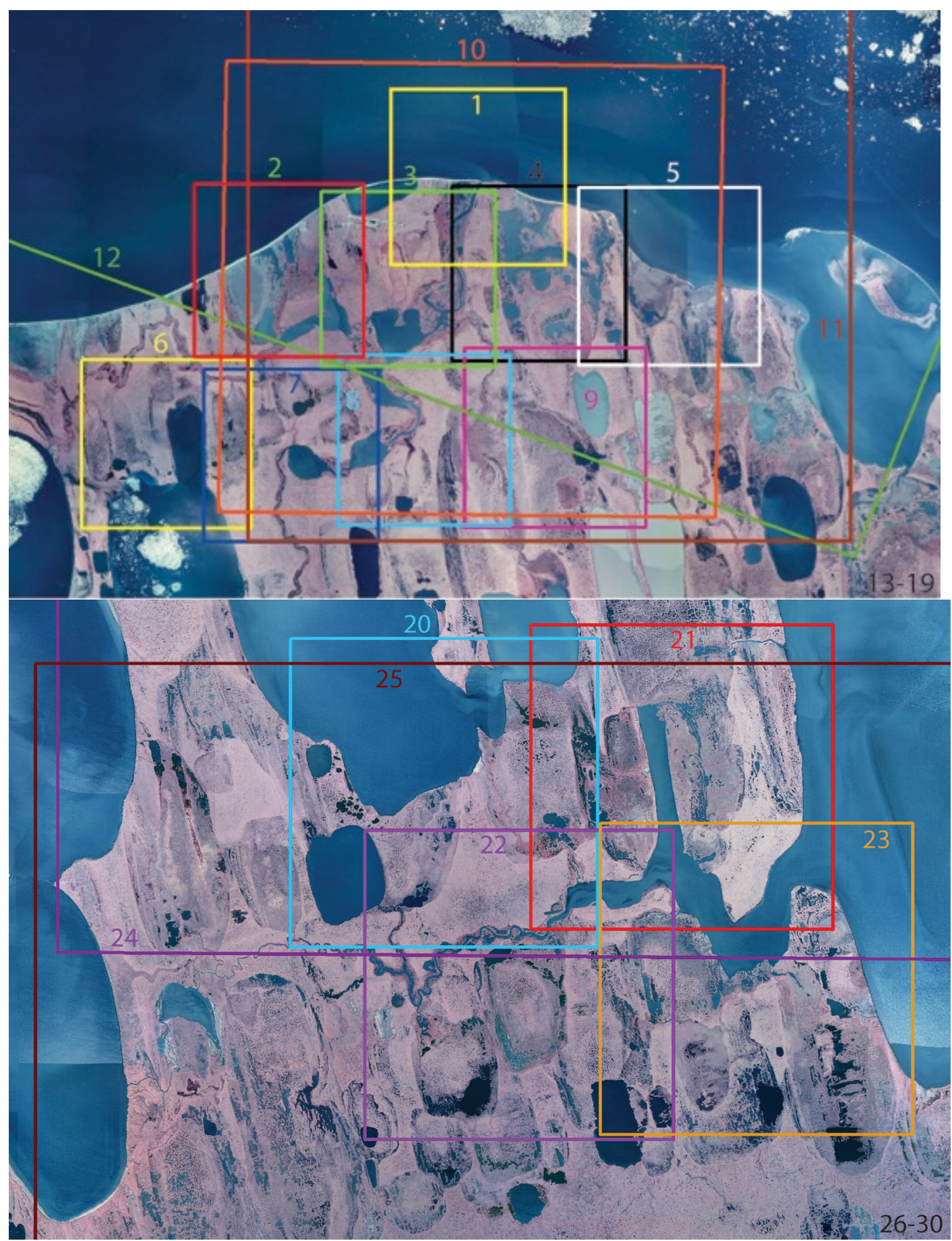




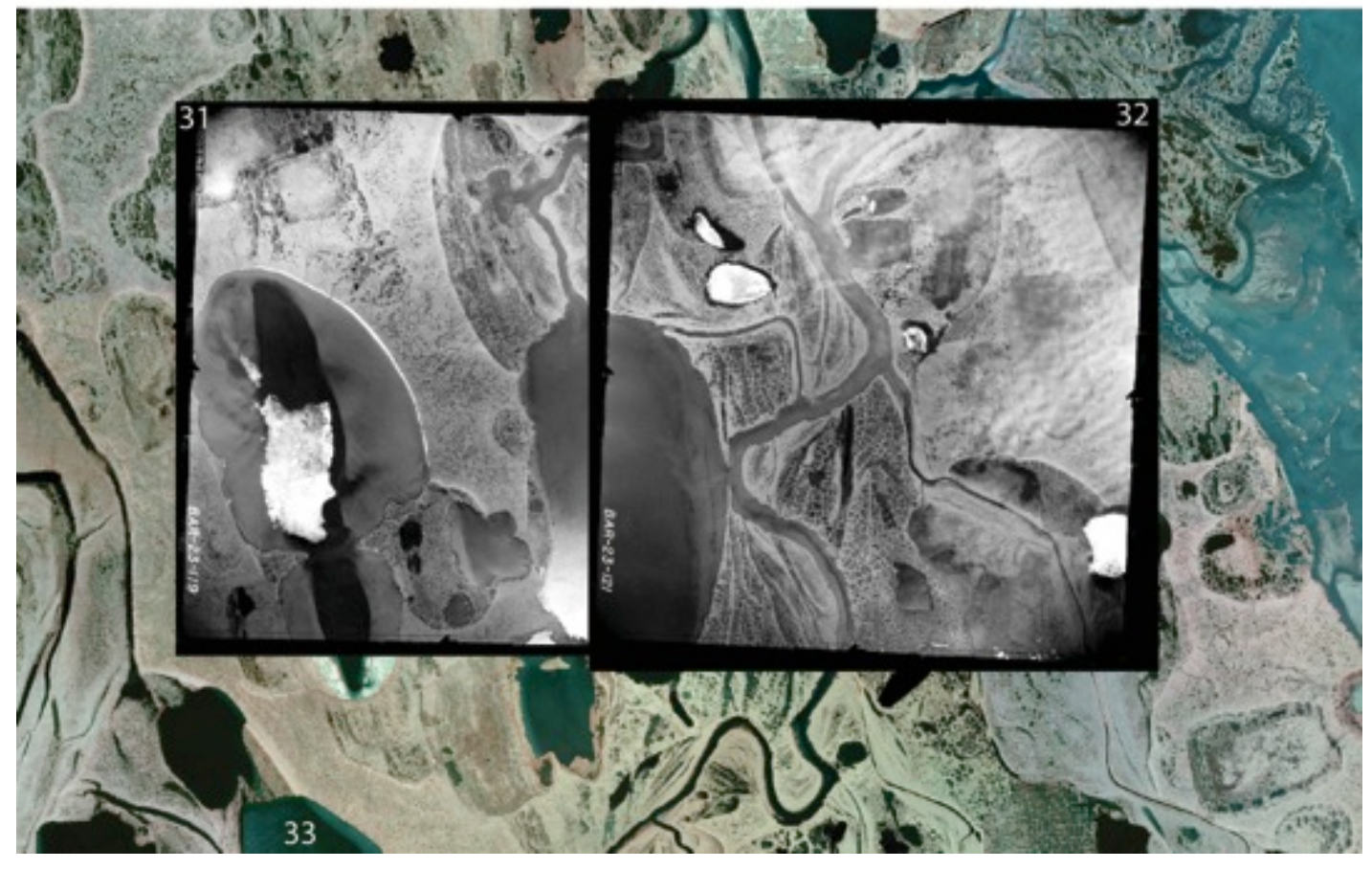

Smith River (top), Garry Creek (middle), and Piasuk River (bottom) study areas. Numbered boxes correspond to image numbers in table 1. Image centerpoints: (top) $\mathrm{N} 70.89^{\circ}, \mathrm{E}-153.15^{\circ}$;

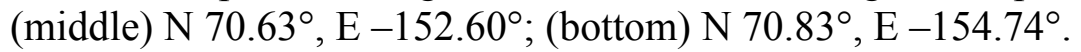


Appendix 2. Mosaic Showing Select Historical and Contemporary Imagery to Assess Ecosystem Change on the Chipp River Study Area on the Arctic Coastal Plain of Northern Alaska.

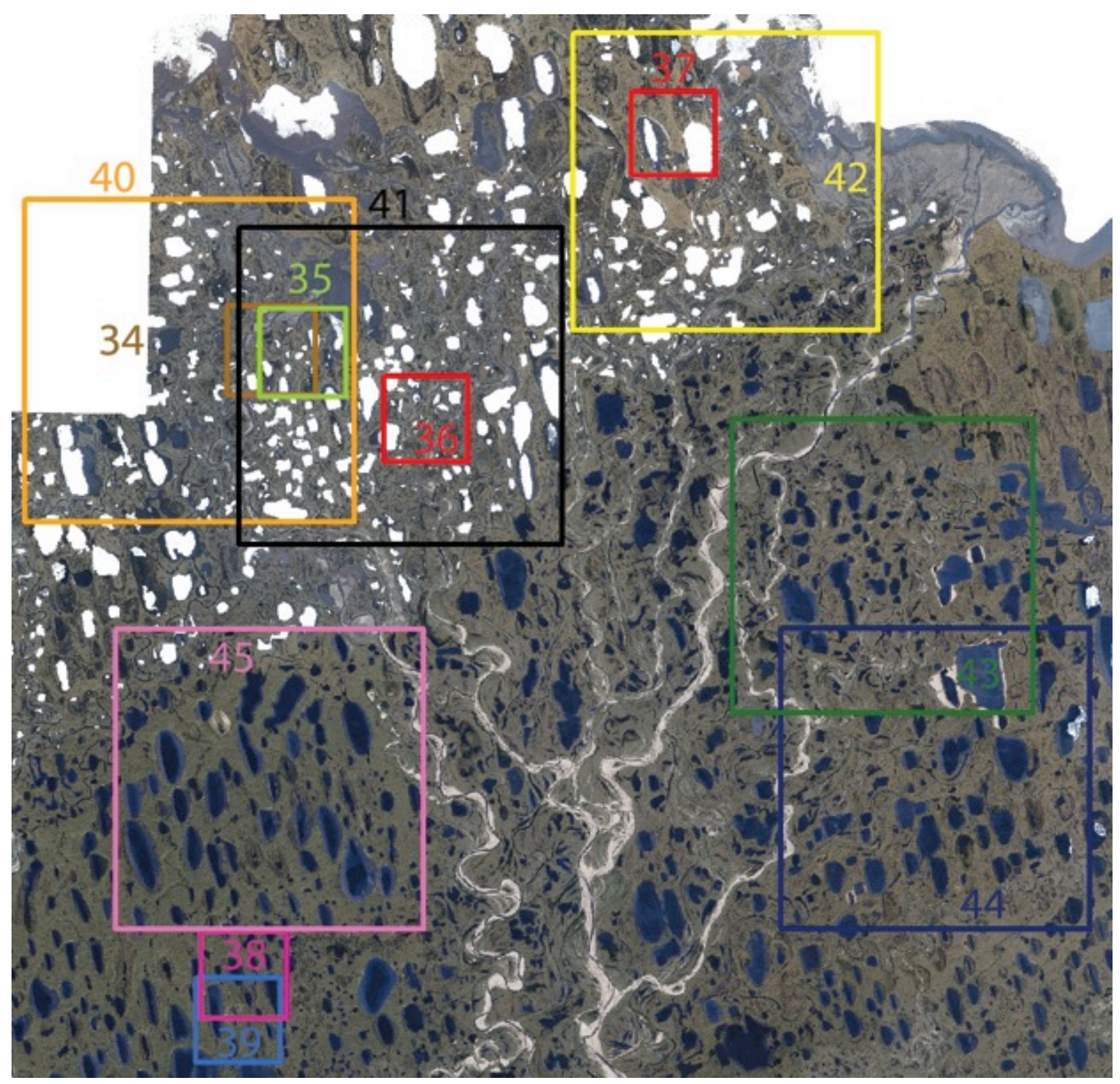

Numbered boxes correspond to image numbers in table 1 . Image centerpoint: N $70.62^{\circ}, \mathrm{E}-$ $154.93^{\circ}$. 
Appendix 3. Mosaic Showing Select Historical and Contemporary Imagery to Assess Ecosystem Change on the Colville River Delta Study Area on the Arctic Coastal Plain of Northern Alaska.

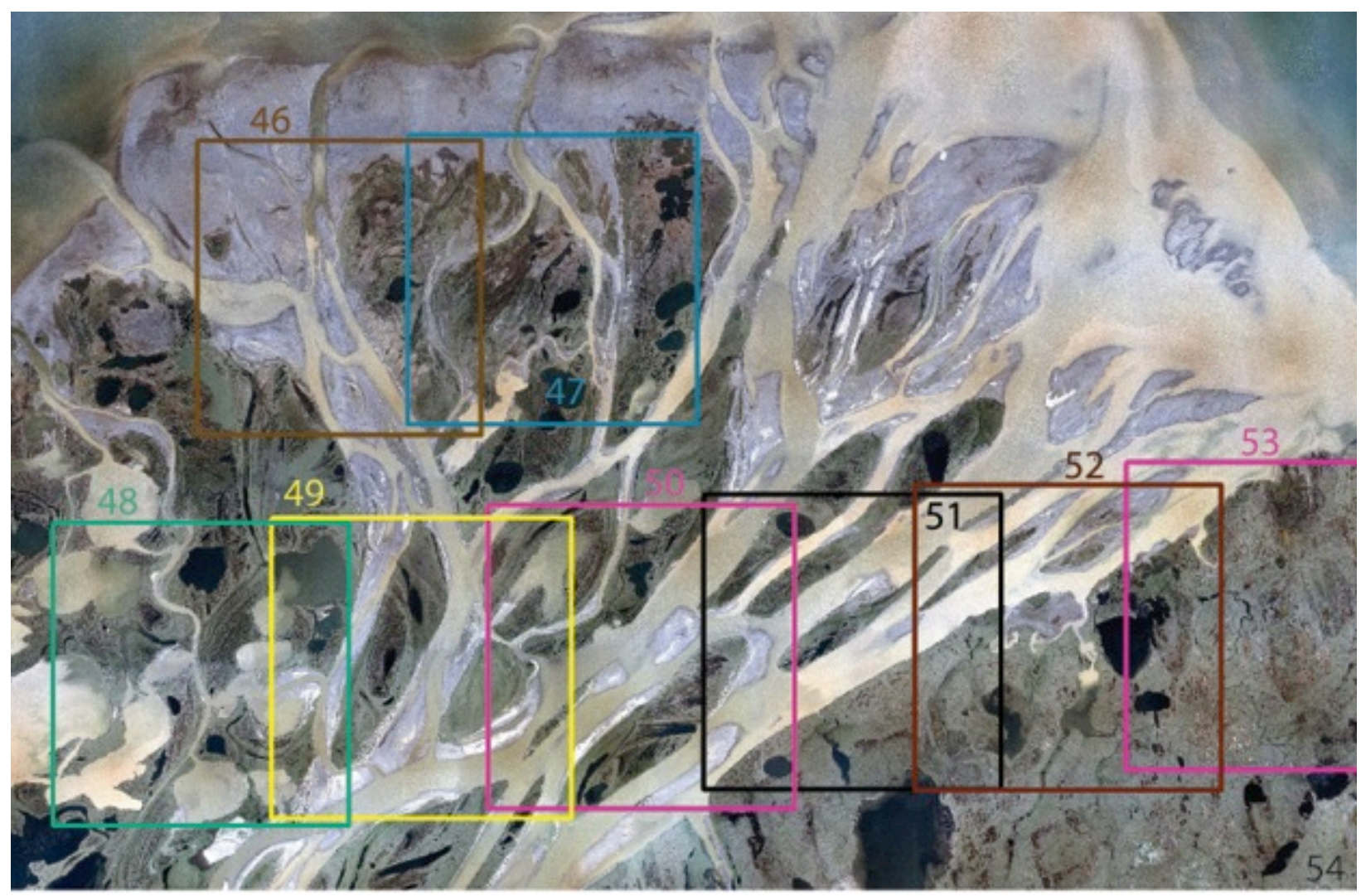

Numbered boxes correspond to image numbers in table 1 . Image centerpoint: $\mathrm{N} 70.43^{\circ}, \mathrm{E}-$ $150.51^{\circ}$. 


\section{Appendix 4. Mosaic Showing Select Historical and Contemporary Imagery to Assess Ecosystem Change on the Dalton Highway Corridor Study Area on the Arctic Coastal Plain of Northern Alaska.}

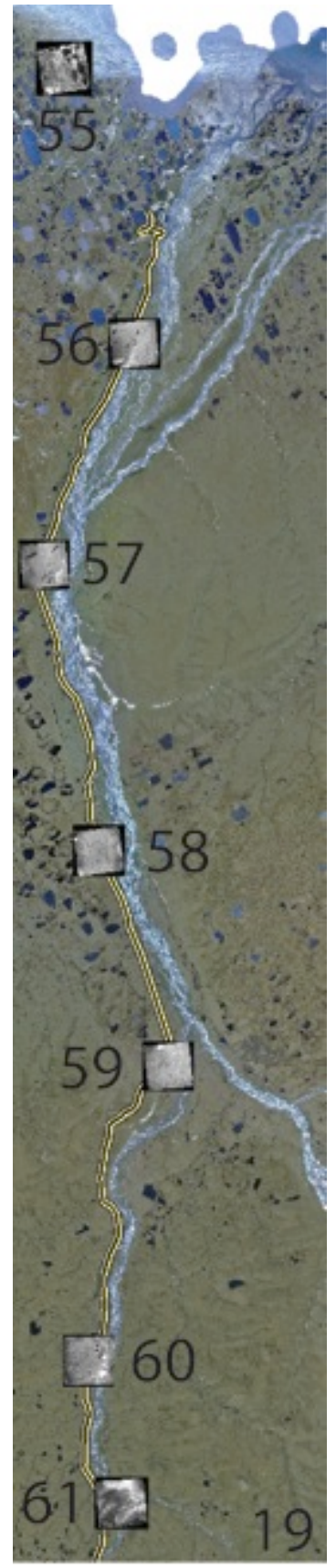

Numbered boxes correspond to image numbers in table 1. Image centerpoint: N 69.75, $\mathrm{E}-148.48^{\circ}$. 
Publishing support provided by the U.S. Geological Survey Publishing Network, Tacoma Publishing Service Center

For more information concerning the research in this report, contact the Director, Alaska Science Center

U.S. Geological Survey

4210 University $\mathrm{Dr}$

Anchorage, Alaska 99508-4560

http://alaska.usgs.gov 


\section{हू}

뭉

ำ

음

D

ซ

음.

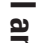

.

일

晋

产

言

$\stackrel{9}{2}$

密 